\title{
COVID-19 in Patients with Primary Immunodeficiency
}

\author{
Saliha Esenboga ${ }^{1}$ (1) $\cdot$ Melike Ocak ${ }^{1} \cdot$ Ayşegul Akarsu ${ }^{1} \cdot$ Hacer Neslihan Bildik ${ }^{1} \cdot$ Deniz Cagdas $^{1} \cdot$ Arzu Topeli Iskit $^{2}$. \\ Ilhan Tezcan ${ }^{1}$
}

Received: 27 January 2021 / Accepted: 12 May 2021 / Published online: 6 July 2021

(c) The Author(s), under exclusive licence to Springer Science+Business Media, LLC, part of Springer Nature 2021

To the Editor,

In December 2019, a new human pathogen, a single-stranded RNA virus named "severe acute respiratory syndrome coronavirus 2" (SARS-CoV-2), appeared in the Hubei province of China [1]. SARS-CoV-2 enters human cells with the help of angiotensin-converting enzyme-2 receptor expressed predominantly in the lung and intestinal epithelial cells, alveolar cells, and vascular endothelial cells and causes an infectious disease (coronavirus disease 2019 (COVID-19)) characterized commonly with pneumonia and acute respiratory distress. The virus mainly spreads through droplet transmission among people, causing a high burden of life-threatening infections and death [2]. Risk factors for severe SARS-CoV2 infection are advanced age, male gender, hypertension, obesity, and cardiovascular disease [3].

Primary immunodeficiencies (PID) result from more than 430 identified genetic defects affecting at least one component of the innate or adaptive immunity, causing susceptibility to specific pathogens [4].

In patients with PID, the course of COVID-19 may vary from asymptomatic to death. Some studies have evaluated the clinical course of COVID-19 in patients with PID and the genetic predisposition or underlying inborn errors of immunity and reported a severe and complicated course of COVID-19 in this patient population [5-9]. However, these studies are very few, and the results are far from proving a clear relationship between PID and severe SARS-CoV2 infection.

In this study, we report the clinical course, follow-up, and outcome of COVID-19 in patients with PID followed at a

Saliha Esenboga

salihaeren@yahoo.com

1 Division of Immunology, Department of Pediatrics, School of Medicine, Faculty of Medicine, Hacettepe University, 06100 Ankara, Turkey

2 Department of Internal Medicine, Faculty of Medicine, Hacettepe University, 06100 Ankara, Turkey tertiary PID center in Turkey with the aim of contributing information regarding the course of the disease.

\section{Method}

We retrospectively analyzed PID patients in our center, Hacettepe University, Department of Pediatric Immunology, who had SARS-CoV2 PCR positivity in nasopharyngeal swap sample. Only cases confirmed with PCR were included in the study. All patients were diagnosed before COVID19 , and the underlying genetic defects were given. In some of our patients, DNA analysis was pending, so the clinical diagnosis was made following European Society of Immunodeficiencies (ESID) guidelines in those patients [10]. A questionnaire surveyed either by phone interview or chart review to collect the patients' demographical data, clinical complications related to their PID disease, treatments for PID and symptoms, transmission route, and clinical manifestations of COVID-19. Lung computed tomography (CT) findings were noted in patients who were evaluated with lung CT.

Information about the place of treatment, the agents used for treatment, and the outcome were given for each patient.

This study was approved by the Ethics Committee of Hacettepe University and the Turkish Ministry of Health. Written informed consent was taken from all patients or their parents as well.

\section{Results}

\section{Patient Characteristics}

Twenty-six patients with PID from a single center had been involved in this cohort. Only patients confirmed by PCR were enrolled in the study. Fourteen $(53.8 \%)$ of the patients were male. The patients' median age was 20.5 (IQR: 9.41-39) years (min: 15 months, max: 46 years). Fifteen of 


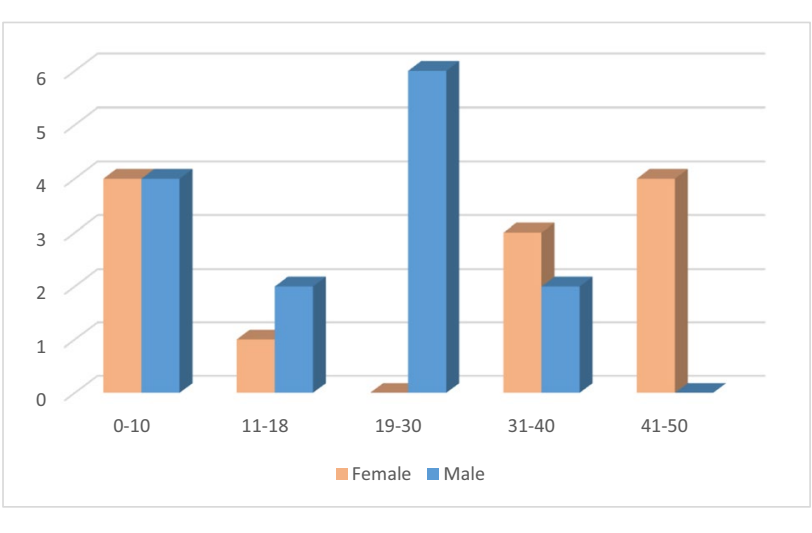

Fig. 1 Distribution of age and sex among patients

the 26 patients were over 18 years of age. The distribution of patients according to sex and age is shown in the supplementary Fig. 1. The median duration of follow-up for PID was 3.5 (IQR: 1-12) years (min: 6 months, max: 17 years). The distribution of the diagnosis of the patients was as combined immunodeficiency (8), CVID (5), immunodeficiencies with immune dysregulation (4), agammaglobulinemia (4), other antibody deficiencies (4), and congenital neutropenia (1). Detailed information on demographical findings, comorbidities of the patients and transmission route, course, and treatment of COVID-19 are given in Table 1. Immunological evaluation of the patients with CIDs is shown in Table 2.

\section{Comorbidities Related to PID}

Fifteen patients (57.7\%) had a history of recurrent pulmonary infections, and four patients had bronchiectasis, and four patients had asthma. Autoimmune diseases (autoimmune hemolytic anemia (AIHA) (4), systemic lupus erythematosus (SLE) (3), Hashimoto thyroiditis (3), diabetes mellitus (DM) (1), juvenile idiopathic arthritis (JIA) (1), autoimmune encephalitis (1), mixed connective tissue disease (1), vitiligo (1), polyarteritis nodosa (PAN) (1)) were present in 12 patients (46.2\%). Twelve patients $(46.2 \%)$ had gastrointestinal complications, including diarrhea, hepatitis, or cirrhosis. Three of five patients with a history of malignancy were cured with chemotherapy; one patient had lowgrade lymphoproliferative disease; one patient had relapsing non-Hodgkin lymphoma with ongoing chemotherapy with rituximab, ifosfamide, carboplatin, and etoposide.

\section{Treatments for PID and Comorbidities}

Three patients did not use any prophylaxis or treatment. Fourteen patients received both immunoglobulin replacement therapy (IGRT) and antibiotic prophylaxis, three received only antibiotic prophylaxis, and five received only IGRT. Nine of the patients were on immunomodulatory and immunosuppressive drugs, including mycophenolate mofetil (MMF), corticosteroid, hydroxychloroquine, sirolimus, abatacept, azathioprine, and methotrexate. Two patients (P1, P22) were transplanted for RASGRP1 $(+4$ years post-HSCT) deficiency and LRBA deficiency $(+2$ years post-HSCT).

\section{Clinical Information and Outcome of COVID-19}

Sixteen patients (61.5\%) were infected with COVID-19 by house contact transmission. Twenty-one patients (80.8\%) had a fever, seven patients had a cough, and six patients had a headache at presentation. Sixteen patients were treated as outpatients, eight patients were hospitalized, and two patients were admitted to intensive care unit. There were patients who received Favipiravir (17); antibiotics (12) including macrolides, meropenem, and piperacillintazobactam; low molecular weight heparin (7); hydroxychloroquine (6); IVIG treatment (4); and Enfluvir (1) for treatment. Two patients had bacterial coinfection, and $H$. influenza was detected in sputum culture. The median time to recovery was 8 (IQR: 7-16) days. Recovery time was extended to 60 days in a patient with a diagnosis of XLA. Ten patients were evaluated by Thorax CT, and seven had parenchymal ground-glass areas and consolidations consistent with COVID-19 pneumonia.

A 46-year-old female patient (P23) with LRBA deficiency and a history of neuroendocrine tumor of the stomach (cured), autoimmune hemolytic anemia, SLE, bronchiectasis, and recurrent diarrhea as comorbidities, and using abatacept and IGRT died, as did a 39-year-old female patient (P5) with combined immunodeficiency, receiving chemotherapy for EBV (+) relapsed non-Hodgkin lymphoma.

\section{Discussion}

At the beginning of the pandemic, our patients with PID were more concerned with the infection risk and sheltered in with exhibiting appropriate behaviors such as using masks, social distancing, and strict self-isolation. So, we did not have any patients with COVID-19 among our PID patients at the onset of the pandemic. With the loosening of the protective measures in the summer of 2020 and the population's exhaustion, with the change in patients' perspective, we started to detect COVID-19 infection in PID patients after July 2020. Here we report the course, followup, outcome, and distribution of 26 patients with PID and COVID-19 so far.

Among our 26 patients, 10 patients were hospitalized (38.4\%), and two patients died. The infection mortality rate was $7.69 \%$, which is eight times higher than the infection mortality rate $(0.97 \%)$ in Turkey's general population. In 


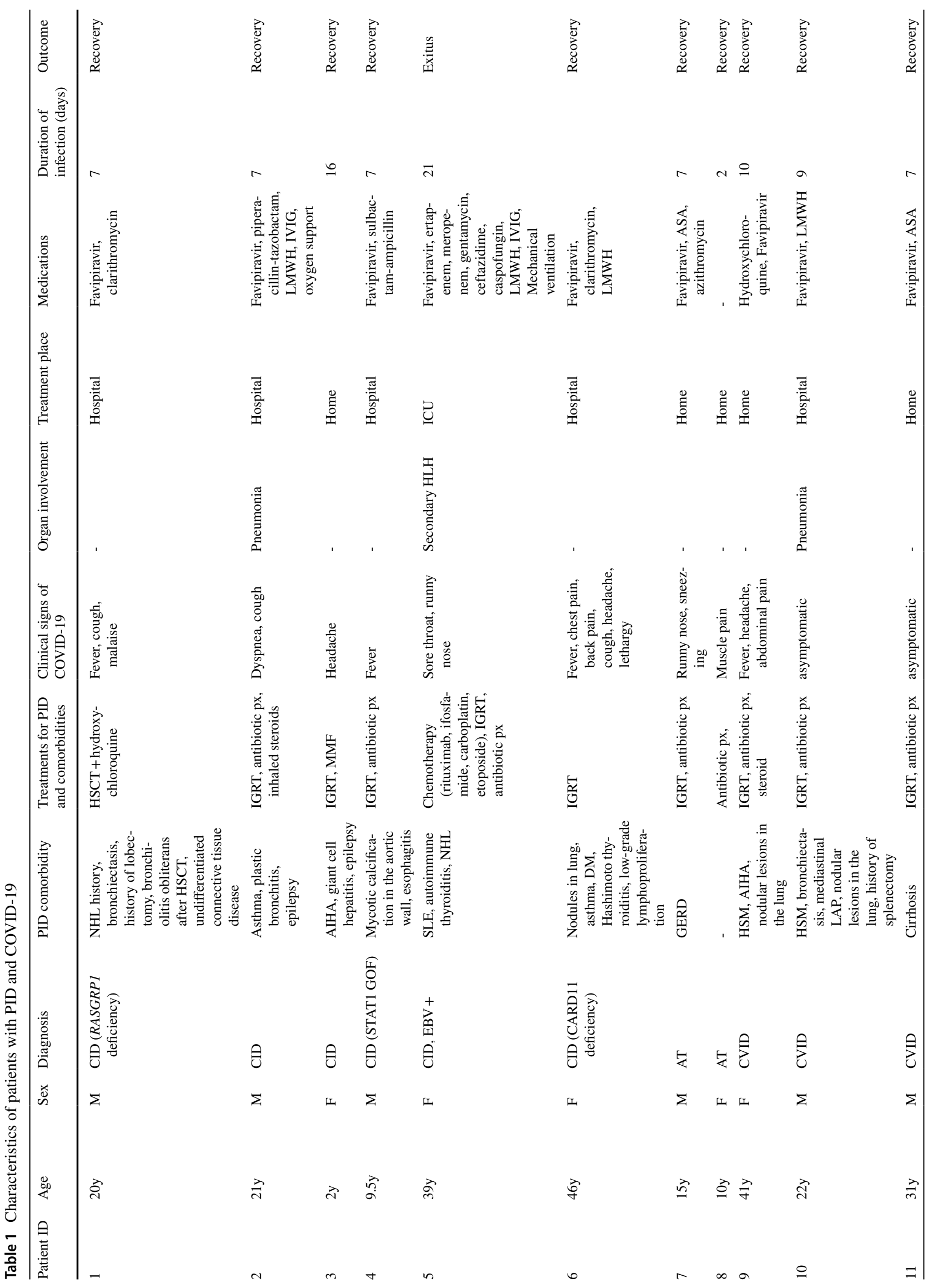




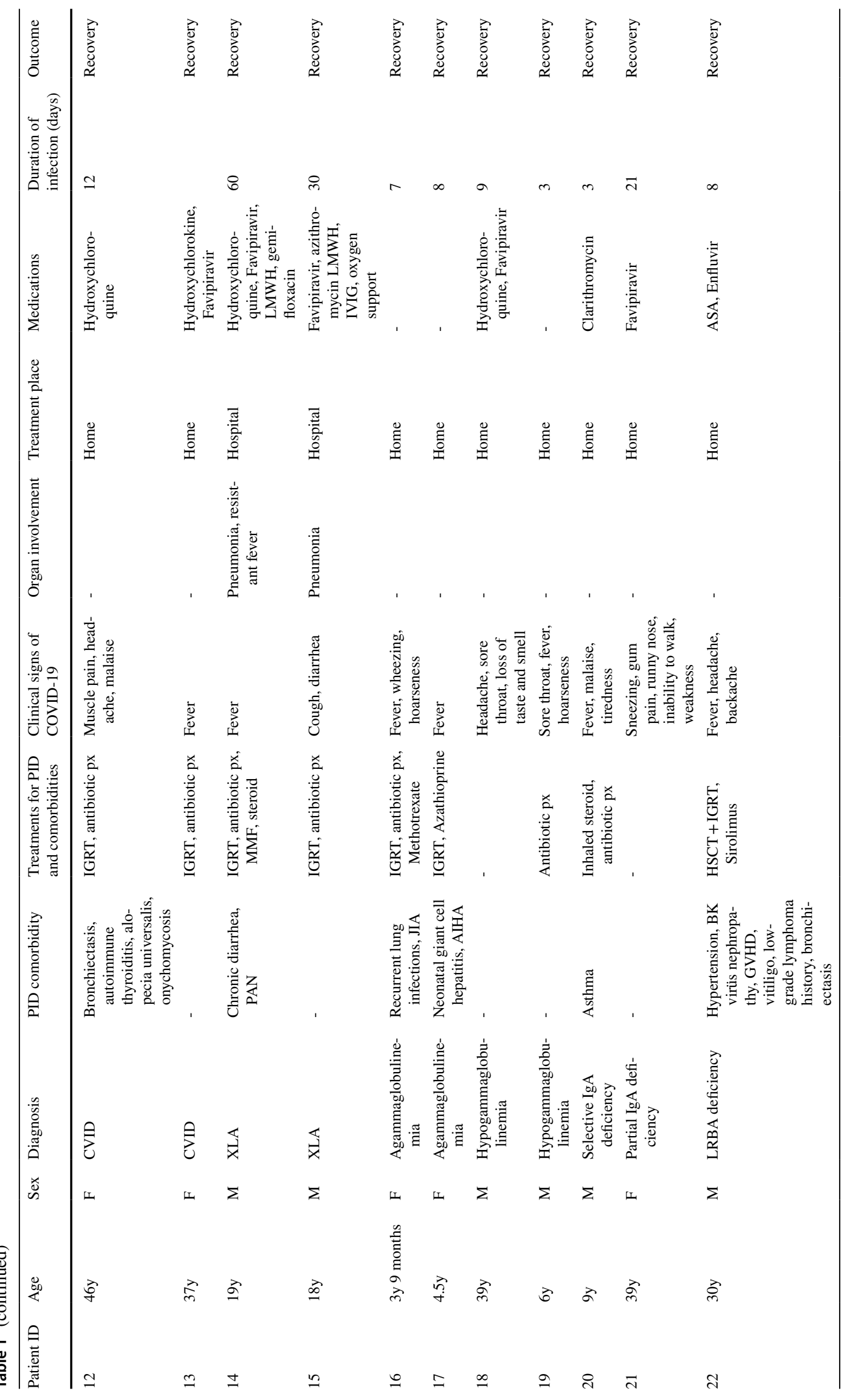




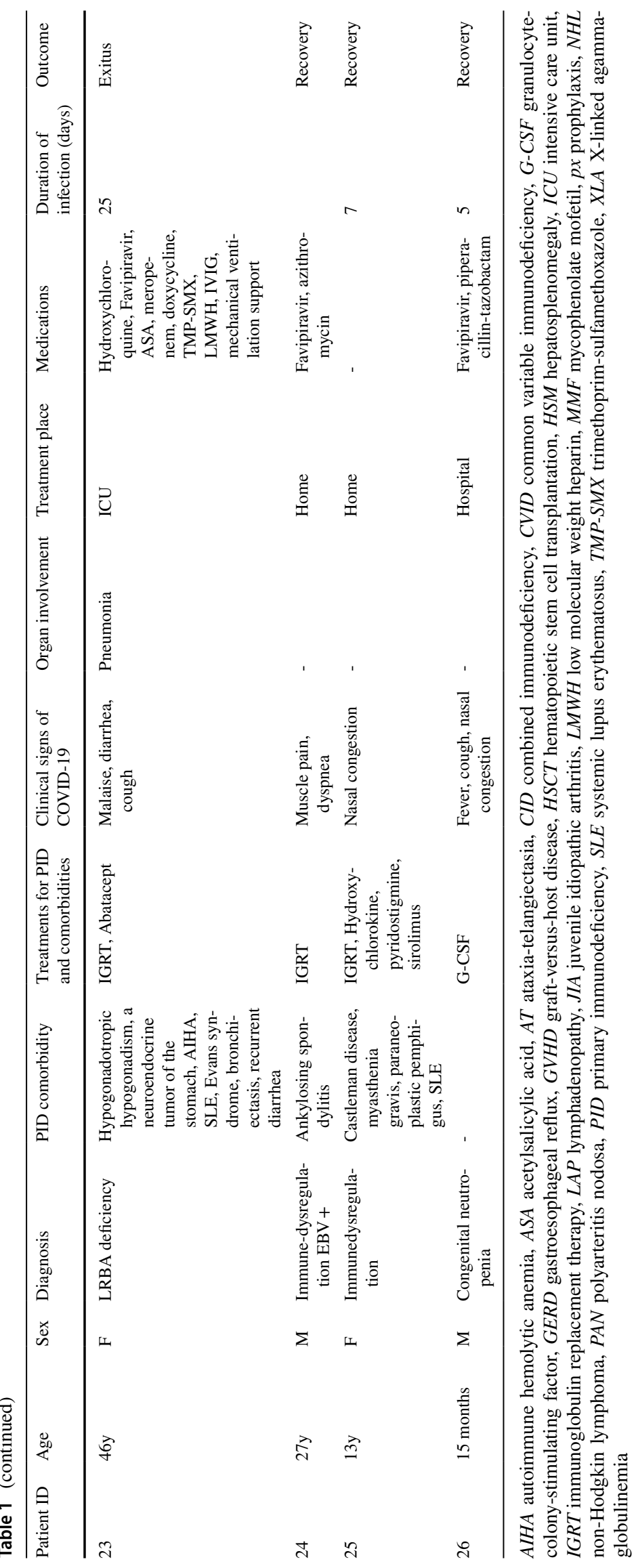


Table 2 Immunological evaluation of the patients with combined immunodeficiencies

\begin{tabular}{|c|c|c|c|c|c|}
\hline Patients & $\begin{array}{l}\text { Absolute lymphocyte } \\
\text { count (ALC) }\left(/ \mathrm{mm}^{3}\right)\end{array}$ & $\begin{array}{l}\text { Immunoglobulins } \\
(\mathrm{mg} / \mathrm{dL})\end{array}$ & $\begin{array}{l}\text { Lymphocyte subsets } \\
\text { \%/absolute counts (/ } \\
\left.\mathrm{mm}^{3}\right)\end{array}$ & $\begin{array}{l}\mathrm{T} \text { and } \mathrm{B} \text { cell subpopu- } \\
\text { lations }\end{array}$ & $\begin{array}{l}\text { Lymphocyte activation/ } \\
\text { transformation }\end{array}$ \\
\hline $\begin{array}{l}\text { P1 (RASGRP1 defi- } \\
\text { ciency) }\end{array}$ & $\begin{array}{l}\text { ALC: } 4064 \text { (1100- } \\
\text { 5900) }\end{array}$ & $\begin{array}{l}\text { IgA: } 660(70-303) \\
\text { IgG:2030 (764-2134) } \\
\text { IgM:188 (69-387) } \\
\text { Total IgE: < 1.00 IU/ } \\
\text { mL }\end{array}$ & $\begin{array}{l}\text { CD3: } 64(55-78) \\
\text { 2600 (700-4200) } \\
\text { CD4: } 13(27-53) \\
528(300-2000) \\
\text { CD8:55 (19-34) } \\
\mathbf{2 2 3 5}(\mathbf{3 0 0 - 1 8 0 0 )} \\
\text { CD16+56: 22(4-26) } \\
894(90-900) \\
\text { CD19:10(10-31) } \\
406(200-1600)\end{array}$ & ND & Low \\
\hline $\mathrm{P} 2$ & $\begin{array}{l}\text { ALC: } 1000(1900- \\
\text { 3700) }\end{array}$ & $\begin{array}{l}\text { IgA: } 134(62-390) \\
\text { IgG:984 (842-1943) } \\
\text { IgM:62.9 (54-392) } \\
\text { Total IgE: } 13.7 \text { IU/ } \\
\text { mL }\end{array}$ & $\begin{array}{l}\text { CD3: } 68(60-76) \\
\mathbf{6 8 0}(\mathbf{1 2 0 0 - 2 6 0 0 )} \\
\text { CD4: 20(31-47) } \\
\mathbf{2 0 0}(\mathbf{6 5 0 - 1 5 0 0 )} \\
\text { CD } 8: 50(18-35) \\
500(370-1100) \\
\text { CD16+56: } 15(4-17) \\
150(100-480) \\
\text { CD19:8 (13-27) } \\
\mathbf{8 0}(\mathbf{2 7 0 - 8 6 0 )}\end{array}$ & $\begin{array}{l}\text { Low memory and } \\
\text { switch memory B } \\
\text { cells } \\
\text { Low naive T cells, } \\
\text { increased effector } \\
\text { memory T cells } \\
\text { RTE: } 6.5 \% \text { (7-100) }\end{array}$ & Low \\
\hline P3 & $\begin{array}{l}\text { ALC: } 1700(3600- \\
\text { 8900) }\end{array}$ & $\begin{array}{l}\text { IgA: } 9.53(\mathbf{3 0 - 1 0 7}) \\
\text { IgG:2140* }(605- \\
\text { 1430) } \\
\text { IgM:10.5 (66-228) } \\
\text { Total IgE: < 1.00 IU/ } \\
\text { mL }\end{array}$ & $\begin{array}{l}\text { CD3: } 87(53-75) \\
\text { 1479 (2100-6200) } \\
\text { CD4: } 57(32-51) \\
969(1300-3400) \\
\text { CD } 8: 35(14-30) \\
\mathbf{5 9 5}(\mathbf{6 2 0 - 2 0 0 0 )} \\
\text { CD16+56: 9(3-15) } \\
\mathbf{1 5 3 ( 1 8 0 - 9 2 0 )} \\
\text { CD19:1(16-35) } \\
\mathbf{1 7}(\mathbf{7 2 0}-\mathbf{2 6 0 0})\end{array}$ & ND & $\begin{array}{l}\text { CD3: } 17(59-80.7) \\
\text { CD25: } 17(86-99.8) \\
\text { CD69: } 25(61.2-91.8) \\
\text { CD3+ CD25+: } 13 \\
(52-93) \\
\text { CD3+ CD69+: } 14 \\
(57-84)\end{array}$ \\
\hline P4 (STAT1 GOF) & $\begin{array}{l}\text { ALC: } 1100(1900- \\
\text { 3700) }\end{array}$ & $\begin{array}{l}\text { IgA: } 142(70-303) \\
\text { IgG:940 (764-2134) } \\
\text { IgM:64.9 (69-387) } \\
\text { Total IgE: } 1.23 \text { IU/ } \\
\text { mL }\end{array}$ & $\begin{array}{l}\text { CD3: } 59(\mathbf{6 0 - 7 6 )} \\
\mathbf{6 4 9}(\mathbf{1 2 0 0 - 2 6 0 0 )} \\
\text { CD4: 28 (31-47) } \\
\mathbf{3 0 8}(\mathbf{6 5 0}-\mathbf{1 5 0 0}) \\
\text { CD } 8: 27(18-35) \\
\mathbf{2 9 7}(\mathbf{3 7 0}-\mathbf{1 1 0 0}) \\
\text { CD16+56: } 19(4-17) \\
209(100-480) \\
\text { CD19:15 (13-27) } \\
\mathbf{1 6 5}(\mathbf{2 7 0 - 8 6 0 )}\end{array}$ & $\begin{array}{l}\text { Low memory and } \\
\text { switch memory B } \\
\text { cells } \\
\text { Low naive T cells, } \\
\text { increased effector } \\
\text { memory T cells } \\
\text { RTE: } 28 \text { (41-81) }\end{array}$ & $\begin{array}{l}\text { CD3: } 35(45-74) \\
\text { CD25: } 58(67-98) \\
\text { CD69: } 17(70-83) \\
\text { CD3 + CD25 + :18(46- } \\
\text { 88.5) } \\
\text { CD3 + CD69+ :15(50- } \\
\text { 75.6) }\end{array}$ \\
\hline $\begin{array}{l}\text { P5 (EBV + lym- } \\
\text { phoma) }\end{array}$ & $\begin{array}{l}\text { ALC: } 2100(1400- \\
3300)\end{array}$ & $\begin{array}{l}\text { IgA: } 120(\mathbf{1 3 9 - 3 7 8 )} \\
\text { IgG:410 (913-1884) } \\
\text { IgM:17.3 (88-322) } \\
\text { Total IgE: } 1.43 \text { IU/ } \\
\text { mL }\end{array}$ & $\begin{array}{l}\text { CD3: } 95(56-84) \\
\text { 1995 }(1000-2200) \\
\text { CD4: } 81(31-52) \\
\text { 1701 }(530-1300) \\
\text { CD8:14 (18-35) } \\
\text { 294 (330-920) } \\
\text { CD16+56: 1 (3-22) } \\
\mathbf{2 1 ~ ( 7 0 - 4 8 0 )} \\
\text { CD19:3 (6-23) } \\
\mathbf{6 3}(\mathbf{1 1 0}-\mathbf{5 7 0})\end{array}$ & $\begin{array}{l}\text { Low naive T cells, } \\
\text { increased effector } \\
\text { memory T cells } \\
\text { RTE: } 1(7-100)\end{array}$ & $\begin{array}{l}\text { CD3: } 44(45-74) \\
\text { CD25: } 38(67-98) \\
\text { CD69: } 25(70-83) \\
\text { CD3 + CD25+: } 35 \\
(46-88.5) \\
\text { CD3 + CD69+: } 15 \\
(50-75.6)\end{array}$ \\
\hline
\end{tabular}


Table 2 (continued)

\begin{tabular}{|c|c|c|c|c|c|}
\hline Patients & $\begin{array}{l}\text { Absolute lymphocyte } \\
\text { count (ALC) }\left(/ \mathrm{mm}^{3}\right)\end{array}$ & $\begin{array}{l}\text { Immunoglobulins } \\
(\mathrm{mg} / \mathrm{dL})\end{array}$ & $\begin{array}{l}\text { Lymphocyte subsets } \\
\text { \%/absolute counts (/ } \\
\left.\mathrm{mm}^{3}\right)\end{array}$ & $\begin{array}{l}\mathrm{T} \text { and B cell subpopu- } \\
\text { lations }\end{array}$ & $\begin{array}{l}\text { Lymphocyte activation/ } \\
\text { transformation }\end{array}$ \\
\hline $\begin{array}{l}\text { P6 (CARD11 defi- } \\
\text { ciency) }\end{array}$ & $\begin{array}{l}\text { ALC: } 2500 \text { (1400- } \\
3300)\end{array}$ & $\begin{array}{l}\text { IgA: } 214(139-378) \\
\text { IgG:1090 (913-1884) } \\
\text { IgM:231 (88-322) } \\
\text { Total IgE: } 154 \text { IU/mL }\end{array}$ & $\begin{array}{l}\text { CD3: } 74(56-84) \\
\text { 1850 (1000-2200) } \\
\text { CD4: 45 (31-52) } \\
\text { 1125 (530-1300) } \\
\text { CD8:26 (18-35) } \\
650(330-920) \\
\text { CD16+56: 8 (3-22) } \\
\text { 200 (70-480) } \\
\text { CD19:14 (6-23) } \\
375(110-570)\end{array}$ & $\begin{array}{l}\text { Low naive T cells, } \\
\text { increased effector } \\
\text { memory T cells } \\
\text { RTE: } 51(7-100)\end{array}$ & $\begin{array}{l}\text { CD3: } 49(45-74) \\
\text { CD25: } 70(67-98) \\
\text { CD69: } 82(70-83) \\
\text { CD3 + CD25+: } 45 \\
(46-88.5) \\
\text { CD3+CD69+: } 45 \\
(50-75.6)\end{array}$ \\
\hline P7 (AT) & $\begin{array}{l}\text { ALC: } 2000 \text { (1900- } \\
3700)\end{array}$ & $\begin{array}{l}\text { IgA: } 8(30-107) \\
\text { IgG:280 (605-1430) } \\
\text { IgM:45 (66-228) } \\
\text { Total IgE: } 1.61 \text { IU/ } \\
\text { mL }\end{array}$ & $\begin{array}{l}\text { CD3: } 70(56-84) \\
\text { 1400 }(1000-2200) \\
\text { CD4: 35 (31-52) } \\
700(530-1300) \\
\text { CD8:42 (18-35) } \\
840(330-920) \\
\text { CD16+56: } 23(3-22) \\
460(70-480) \\
\text { CD19:4 (6-23) } \\
\mathbf{8 0 ( 1 1 0 - 5 7 0 )}\end{array}$ & ND & ND \\
\hline P8 (AT) & $\begin{array}{l}\text { ALC: } 1400(1900- \\
\text { 3700) }\end{array}$ & $\begin{array}{l}\text { IgA: } 13.6(\mathbf{3 0 - 1 0 7 )} \\
\text { IgG:423 (605-1430) } \\
\text { IgM:154 (66-228) } \\
\text { Total IgE: } 5.54 \text { IU/ } \\
\text { mL }\end{array}$ & $\begin{array}{l}\text { CD3: } 68(60-76) \\
\text { 952 (1200-2600) } \\
\text { CD4: } 48(31-47) \\
672(650-1500) \\
\text { CD8:15 (18-35) } \\
\mathbf{2 1 0}(\mathbf{3 7 0}-\mathbf{1 1 0 0}) \\
\text { CD16+56: } 17(4-17) \\
238(100-480) \\
\text { CD19:13 (13-27) } \\
\mathbf{1 8 2}(\mathbf{2 7 0}-\mathbf{8 6 0})\end{array}$ & ND & ND \\
\hline
\end{tabular}

The abnormal values are shown in bold

a study conducted in the UK, the hospitalization rate was $53.3 \%$ among 60 PID patients; 12 patients died, and the infection mortality rate was reported as $20 \%$ [11]. An international study with 94 patients with PID documented the death of $9(9.57 \%)$ patients during follow-up [5]. In a study conducted in Iran, located in a similar geographical region with our country, 8 of 19 PID patients died, and the mortality rate was found to be $42.1 \%$ that is ten times higher than the general population in Iran [12]. This diversity of hospitalization and mortality rates in different studies may be associated with the fact that PIDs are a highly heterogeneous group of diseases, and severity varies quitely with PID-related comorbidities. Another factor affecting the difference between mortality rates among studies may be the number of pediatric patients included. None of our patients were above 50 years of age; 11 out of 26 were children in our study group, which may be one explanation of lower mortality than other studies. In summary, although the groups are heterogeneous, as in all studies, mortality in patients with PID is higher than in the general population in our study.
In our study, none of our patients with CVID or agammaglobulinemia died, and hospitalization rates were similar. It was stated that among the primary antibody deficiencies, CVID patients had a more severe course than those with XLA $[13,14]$. On the contrary, in our cohort, two XLA patients had a more severe course with a more extended hospital stays which extended to 60 days. It seems difficult to identify any group as more risky among antibody deficiencies.

Combined immunodeficiency was the most common PID in our study. The hospitalization rate of patients with CID was $62.5 \%$. Among PID groups, combined immunodeficiencies had the highest hospitalization rate.

A 39-year-old patient with CID and EBV + relapsing lymphoma (P5) developed COVID-19 while receiving active chemotherapy at the hospital and died in ICU due to secondary HLH. A patient with CID due to RASGRP1 deficiency(P1) with comorbidities showed favorable outcome. It is noteworthy that this patient had attained curative treatment with HSCT 4 years ago.

Among the patients with immunedysregulation, a 46-yearold female patient (P23) with LRBA deficiency died. She had a 
history of neuroendocrine tumor of the stomach (cured), autoimmune hemolytic anemia, SLE, bronchiectasis, and recurrent diarrhea as comorbidity and was using abatacept and IGRT. However, another 30-year-old patient with LRBA deficiency (P22) and with comorbidities was treated at home without any complication due to COVID-19. It is also noteworthy that this patient had attained curative treatment with HSCT 2 years ago.

Both patients who died in our cohort had a potential of uncontrolled immune response due to CID and immunodeficiency with immune dysregulation. The study from Iran also revealed that the most lethal COVID-19 was seen in patients with SCID and familial hemophagocytic lymphohistiocytosis with 150 folds higher risk of mortality [12]. In the case of combined immunodeficiency, disease severity will be increased due to the impaired cellular immunity and viral control. In the case of immune dysregulation, uncontrolled inflammatory responses may also make the patients more susceptible to the COVID-19 [15].

One of the most striking points in our study is the outcome of 2 male patients who transplanted for RASGRP1 deficiency and LRBA deficiency. Although they had various comorbidities (history of bronchiectasis and lobectomy, hypertension, BK virus nephropathy), the outcome was favorable.

Although it is clear that mortality in patients with PID is higher than in the general population, it is difficult to suggest a riskier group among primary immunodeficiencies for COVID19 with a complicated course, according to the data published so far. The groups are quite heterogeneous regarding age, sex, and comorbidities, but, remarkably, patients who underwent HSCT with curative treatment had an uncomplicated course despite comorbidities. Future studies or metaanalysis combining the published data may help to better understand the clinical course of COVID-19 in patients with PID.

Supplementary Information The online version contains supplementary material available at https://doi.org/10.1007/s10875-021-01065-9.

Acknowledgements We thank all physicians and nurses for their invaluable support and care for patients with PID and COVID 19.

Author Contribution All authors contributed to the study's conception and design. MO, HNB, and AA collected the data. SE performed the analysis and wrote the first draft of the manuscript. DC, ATI, and IT commented on the document and improved the discussion. All authors read and approved the final manuscript.

Data Availability On a reasonable request, the data supporting study's findings are available from the corresponding author.

\section{Declarations}

Ethical Approval This study was approved by the Ethics Committee of Hacettepe University and the Turkish Ministry of Health.

Consent to Participate Informed consent was taken from all patients and/or their parents as well.
Conflict of Interest The authors declare no competing interests.

\section{References}

1. Zhu N, Zhang D, Wang W, et al. A novel coronavirus from patients with pneumonia in China, 2019. N Engl J Med. 2020;382:727-33.

2. Yao Y, Wang H, Liu Z. Expression of ACE2 in airways: Implication for COVID-19 risk and disease management in patients with chronic inflammatory respiratory diseases. Clin Exp Allergy. 2020;50(12):1313-24.

3. Huang C, Wang Y, Li X, et al. Clinical features of patients infected with 2019 novel coronavirus in Wuhan, China. Lancet. 2020;395:497-506.

4. Tangye SG, Al-Herz W, Bousfiha A, et al. Human inborn errors of immunity: 2019 update on the classification from the International Union of Immunological Societies Expert Committee. J Clin Immunol. 2020;40:24-64.

5. Meyts I, Bucciol G, Quinti I, et al. Coronavirus disease 2019 in patients with inborn errors of immunity: An international study. J Allergy Clin Immunol. 2021;147(2):520-31.

6. Ho HE, Mathew S, Peluso MJ, Cunningham-Rundles C. Clinical outcomes and features of COVID-19 in patients with primary immunodeficiencies in New York City. J Allergy Clin Immunol Pract. 2021;9(1):490-493.e2.

7. Babaha F, Rezaei N. Primary immunodeficiency diseases in COVID-19 pandemic: a predisposing or protective factor? Am J Med Sci. 2020;360:740-1.

8. Zhang Q, Bastard P, Liu Z, et al. Inborn errors of type I IFN immunity in patients with life-threatening COVID-19. Science. 2020;370:eabd4570.

9. Bastard P, Rosen LB, Zhang Q, et al. Autoantibodies against type I IFNs in patients with life-threatening COVID-19. Science. 2020;370:eabd4585.

10. Seidel MG, Kindle G, Gathmann B, et al. The European Society for Immunodeficiencies (ESID) registry working definitions for the clinical diagnosis of inborn errors of immunity. J Allergy Clin Immunol Pract. 2019;7:1763-70.

11. Shields AM, Burns SO, Savic S, Richter AG; UK PIN COVID19 Consortium. COVID-19 in patients with primary and secondary immunodeficiency: The United Kingdom experience. J Allergy Clin Immunol. 2021;147(3):870-75.

12. Delavari S, Abolhassani H, Abolnezhadian F, et al. Impact of SARS-CoV-2 pandemic on patients with primary immunodeficiency. J Clin Immunol. 2021;41(2):345-55.

13. Quinti I, Lougaris V, Milito C, et al. A possible role for B cells in COVID-19? Lesson from patients with agammaglobulinemia. J Allergy Clini Immunol. 2020;146:211-3.e4.

14. Soresina A, Moratto D, Chiarini M, Paolillo C, Baresi G, Focà E, Bezzi M, Baronio B, Giacomelli M, Badolato R. Two X-linked agammaglobulinemia patients develop pneumonia as COVID-19 manifestation but recover. Pediatr Allergy Immunol. 2020;31(5):565-9.

15. Hammarstrom L, Abolhassani H, Baldanti F, et al. Development of passive immunity against SARS-CoV-2 for management of immunodeficient patients-a perspective. J Allergy Clin Immunol. 2020;146:58-60.

Publisher's Note Springer Nature remains neutral with regard to jurisdictional claims in published maps and institutional affiliations. 